\title{
Acute and Ninety-day Oral Toxicity of the Water Extract from the Fresh Leaves of Pseuderanthemum palatiferum in Rats
}

\author{
Parirat Khonsung $^{1^{*}}$, Natthakarn Chiranthanut ${ }^{1}$, Ampai Panthong ${ }^{1}$, \\ Sunee Chansakaow ${ }^{2}$, Sophaphan Intahphuak, \\ and Seewaboon Sireeratawong ${ }^{1}$
}

\begin{abstract}
${ }^{1}$ Department of Pharmacology, Faculty of Medicine, Chiang Mai University, Chiang Mai 50200, Thailand

${ }^{2}$ Department of Pharmaceutical Sciences, Faculty of Pharmacy, Chiang Mai University, Chiang Mai 50200, Thailand

${ }^{3}$ School of Nursing, Mae Fah Luang University, Chiang Rai 57100, Thailand
\end{abstract}

*Corresponding author. Email: wparirat@yahoo.com https://doi.org/10.12982/CMUJNS.2020.0061

Received: November 25, 2019

Revised: April 7, 2020

Accepted: April 17, 2020

\begin{abstract}
The objectives of this study were to assess acute and ninety-day oral toxicity of the water extract from the fresh leaf of $P$. palatiferum in rats. Acute oral toxicity study was conducted by a single administration $2,000 \mathrm{mg} / \mathrm{kg}$ of the water extract to female rats. The clinical signs related to toxic effects and the mortality of the rats were observed for a 14-day further. Repeated dose oral toxicity study was performed in both sexes of rats by giving $1,000 \mathrm{mg} / \mathrm{kg}$ of the extract once daily for 90 days. The toxic signs and health of the animals were monitored. At the end of the study, blood and the internal organs were collected for chemistry assay and the histopathological examination, respectively. The results revealed no significant difference between the control and treated rats in the acute oral toxicity study. There was no death of animals during 90-day orally given the water extract. All assessed parameters were similar to those of the control rats and were within the normal range. No significant pathologic feature and no difference between the groups of the animals were observed. In conclusion, the water extract of the fresh leaf of $P$. palatiferum at the single oral dose of $2,000 \mathrm{mg} / \mathrm{kg}$ produces neither any acute toxicity signs nor mortality in female rats. The daily dose of $1,000 \mathrm{mg} / \mathrm{kg}$ of the extract repeated administration for 90 days reveals well tolerance and safety profile in both sexes of rats.
\end{abstract}


Keywords: Pseuderanthemum palatiferum, Water extract, Acute oral toxicity, Ninety-day oral toxicity

\section{INTRODUCTION}

The leaf of Pseuderanthemum palatiferum (Nees) Radlk, family Acanthaceae, was dosed for both treatment and prevention of many diseases and symptoms e.g., wound, stomachache, diarrhea, and high blood pressure (Dieu et al., 2006). The dose for prevention and treatment are approximately 3 to 6 and 7 to 9 fresh leaves, respectively (Dieu et al., 2005). Numerous pharmacological activities of $P$. palatiferum has been reported including antibacterial and antifungal activities (Nguyen and Eun, 2013), antidiarrheal activity (Dieu et al., 2006), hypoglycemic activity (Padee et al., 2010; Panomket and Wanram, 2011), anti-inflammatory activity (Khumpook et al., 2013), acetylcholinesterase inhibitory activity in the hippocampus of the rats (Buncharoen et al., 2010), cytotoxic activity against lung cancer cell and antioxidant activity (Dechayont et al., 2010), and anti-cancer activity against MDA-MB-231 human breast cancer cells (Komonrit and Banjerdpongchai, 2018) and A549 human lung cancer cells (Kongprasom et al., 2019).

Phytochemical study of $P$. palatiferum leaf revealed the high contents of amino acids and mineral elements (Dieu et al., 2005), $\beta$-sitosterol, kaempferol, stigmasterol, triterpenoid saponins, apigenin, phytol, flavonoids, palmitic acid, and salicylic acid (Padee and Nualkaew, 2009).

Evaluation of the safety of herbal medicine in animals provides valuable information for further clinical study and the development of the medicinal plant product used in primary health care. The previous study of an $80 \%$ ethanol extract of dry leaf of $P$. palatiferum showed no cytotoxicity in vero cells and caused neither signs nor symptoms of toxicity in single-dose and once-daily administration for 14 days in male Wistar rats (Padee et al., 2009). As the potential botanical applications to treat chronic diseases of the plant, however, the fresh leaf of $P$. palatiferum has been used. The water extract from the leaf of $P$. palatiferum reveals the hypotensive and bradycardic activities (Khonsung et al., 2011), anti-inflammatory and analgesic activities (Inchab et al., 2019), and gastroprotective activity (Inchab et al., 2018). This study aimed to assess acute and ninety-day oral toxicity of the water extract of the fresh leaf of $P$. palatiferum in rats because some signs and symptoms of toxicity may appear after repeated exposure. 


\section{MATERIAL AND METHODS}

\section{Materials}

The fresh leaf of $P$. palatiferum was gathered in Chiang Mai, Thailand and the specimen (QBG. 42335) has been kept at the Queen Sirikit Botanic Garden (QBG) herbarium Chiang Mai, Thailand.

\section{Preparation of water extract}

Fresh leaves were milled and macerated in distilled water. Four hours later, the water extract was filtrated and evaporated to dryness. The percentage yield was $5.68 \%(\mathrm{w} / \mathrm{w})$ of raw materials. The extract was dissolved in distilled water before use.

\section{Chromatographic analysis of the water extract of $P$. palatiferum}

HPLC Chromatogram was carried out using Shimadzu LC-20A series instrument (Shimadzu, Japan) with UV detection at $280 \mathrm{~nm}$. The columns were Inertsil ODS-3 C18 reversed phase columns with thermostatically control at 28 ${ }^{\circ} \mathrm{C}$ and a mobile phase was a mixture of acetonitrile (line A) and $1.0 \%$ of acetic acid in water (line B). The elution gradient was changed from 10-40\% of solvent A for $28 \mathrm{~min}$, from $40-90 \%$ of solvent $\mathrm{A}$ in $39 \mathrm{~min}$ and back to the initial condition for $10 \mathrm{~min}$. The sample $(1 \mathrm{mg} / \mathrm{mL})$ was injected in a volume of $10 \mu \mathrm{L}$ to HPLC by an autosampler. The flow rate of the system was $0.7 \mathrm{~mL} / \mathrm{min}$. Gallic acid, tannic acid, kaemferol, and quercetin were used as chemical markers.

\section{Experimental animals}

Six-week-old Sprague Dawley rats (150-180 g) were purchased from the National Laboratory Animal Center, Nakorn Pathom, Thailand. Both male and female rats were housed in the temperature and light controlled room $\left(24 \pm 1^{\circ} \mathrm{C}\right.$, $12 \mathrm{~h}$ light-dark cycle). The free drinking water and standard diet (C.P. MICE FEED, S.W.T. Co., Ltd., Samut Prakan, Thailand) were allowed. Animals were kept 1 week for adaptation prior to starting the study. All experiments had been approved by the Animal Ethics Committee, Faculty of Medicine, Chiang Mai University (No. 24/2552).

\section{Acute toxicity study}

According to OECD Test Guideline 420, the main study of acute toxicity was considered using $2,000 \mathrm{mg} / \mathrm{kg}$ of the water extract of fresh leaf of $P$. palatiferum. The treated female group and the control female group were administered the water extract at the dose of $2,000 \mathrm{mg} / \mathrm{kg}$ and distilled water, respectively. Toxic and clinical signs were observed after the administration of the extract 1,2, 4 and $6 \mathrm{~h}$ and every day for 2 weeks. The clinical signs related to toxic effects and the mortality of the rats were recorded (OECD, 2002). 


\section{Repeated dose 90-day oral toxicity study}

Following OECD Test Guideline 408, the limit test was conducted using $1,000 \mathrm{mg} / \mathrm{kg}$ of the extract. The control and the treatment groups (10 male and 10 female rats in each group) received distilled water or the extract $(1,000 \mathrm{mg} / \mathrm{kg} / \mathrm{d})$ for 90 days, respectively. Two extra groups including the control satellite and the treatment satellite groups were given orally distilled water or the extract $(1,000$ $\mathrm{mg} / \mathrm{kg} / \mathrm{d}$ ) for 90 days and then kept for further 14 days to examine the reversibility or the delayed events of toxic effects.

During the period of the experiment, the body weight of rats and the observation of toxic signs were assessed. Any rats died during the period of observation were examined for disorders. At the end of the experiment, all surviving animals were fasted for 16-18 h before anesthetization with thiopental sodium $(50 \mathrm{mg} / \mathrm{kg}$, i.p.). The heparinized blood from a common carotid artery was collected and determined for complete blood count (WBC, differential leukocyte count, red blood cell count, hematocrit, hemoglobin, and platelet) by HumaCount Plus Hematology Analyzer. The serum from non-heparinized blood was assayed for blood chemistry parameters, liver function, and renal function. The parameters were automatically determined using the Vitalab Flexor E chemistry Analyzer. The internal organs including the heart, lungs, livers, spleen, kidneys, adrenals, and sex organs were weighed and histopathologically examined (OECD, 2018).

\section{Statistical analysis}

Data were expressed as mean \pm standard error of the mean (S.E.M.). The statistically significant difference between groups was analyzed by one-way analysis of variance (ANOVA) and post hoc least-significant difference (LSD) test in 90-day toxicity study and using Student's $t$-test in acute toxicity study. $P$ values less than 0.05 were considered significant.

\section{RESULTS}

\section{Chromatographic analysis of the water extract of $\boldsymbol{P}$. palatiferum}

Standard gallic acid, tannic acid, kaemferol, and quercetin were shown in HPLC chromatograms at retention time (Rt) 4.17, 4.19, 32.11 and $30.21 \mathrm{~min}$, respectively. Comparative to the chemical markers, gallic (Rt 4.17) and tannic acid (Rt 4.19) were only minor constituents in the water extract and the major peaks at Rt 16.10 and 26.68 min are still unknown (Figure 1). 


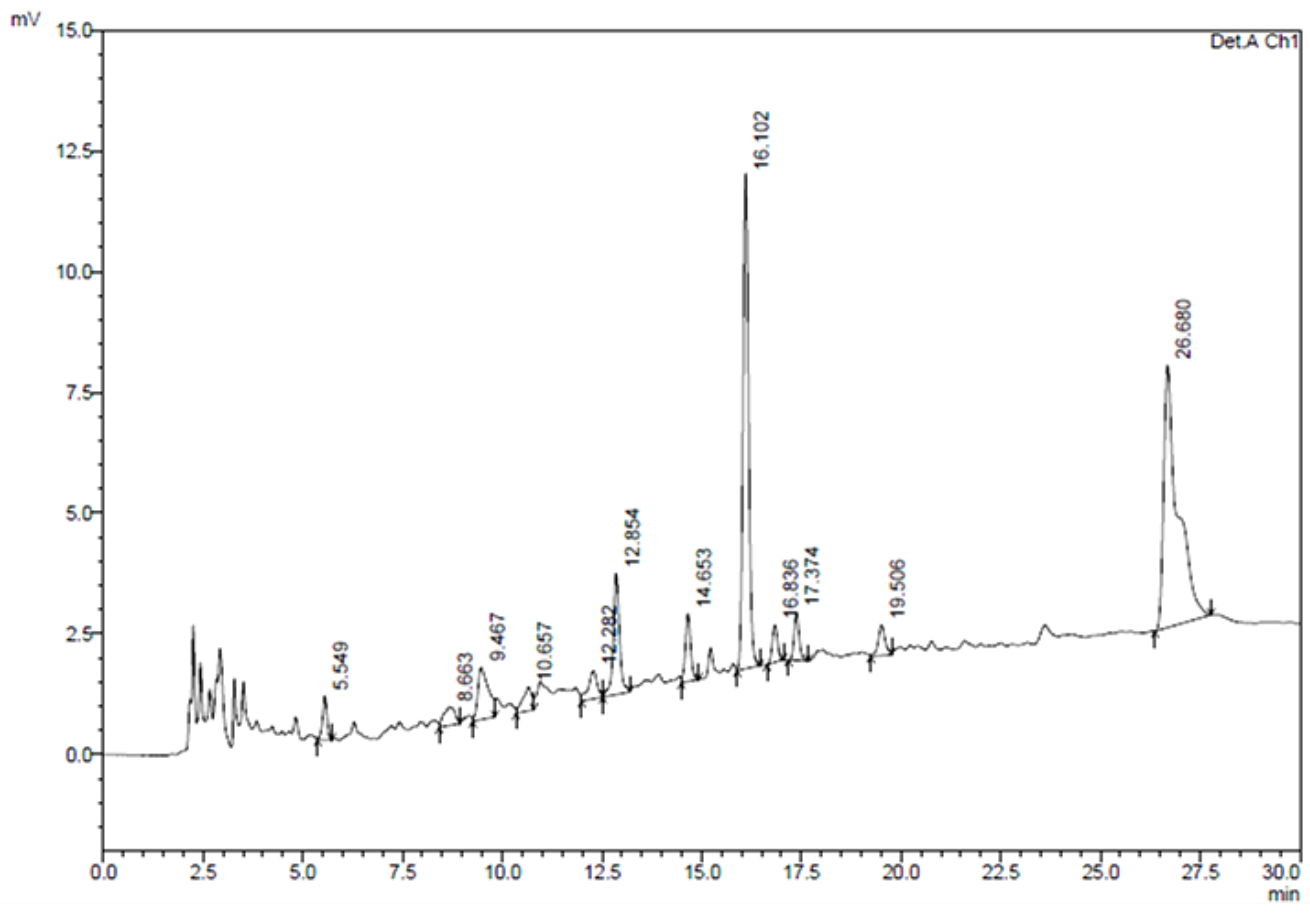

Figure 1. HPLC chromatograms of the water extract of the fresh leaf of P. palatiferum.

\section{Acute toxicity study}

During 14 day-observation, the single oral dose of the water extract of the fresh leaf of $P$. palatiferum $(2,000 \mathrm{mg} / \mathrm{kg})$ did not cause mortality of female rats. Any toxicity signs or changes in general behavior were not observed. The body weight gain was not significantly different when compared between the treated rats and the control rats (Figure 2).

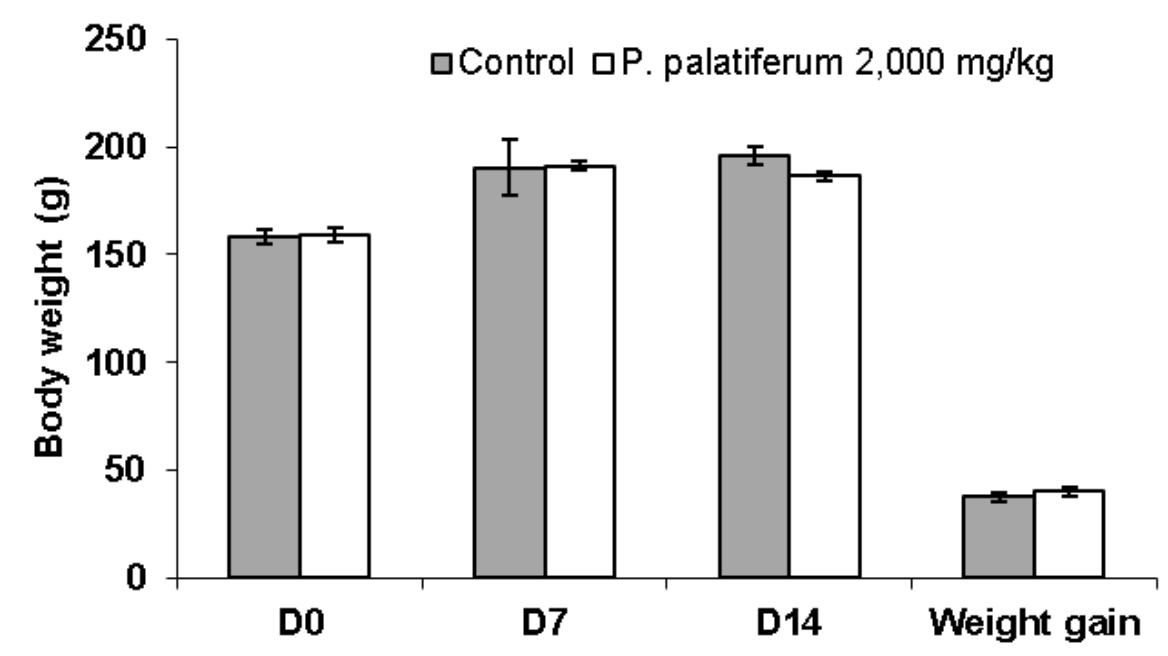

Figure 2. Body weight of the female rats in acute toxicity test. 


\section{Repeated Dose 90-day Oral Toxicity Study}

There was no death of animals during 90-day orally given of the water extract of the fresh leaf of $P$. palatiferum $(1,000 \mathrm{mg} / \mathrm{kg})$. The animals did not show signs of toxic throughout the observation. Growth curves of male and female rats are shown in Figure 3. The body weights of treated male rats were slightly higher but not significant when compared to that of the control male rats. No significant difference between the body weight gain in week 13 of male rats $(236.60 \pm 10.68 \mathrm{~g}$ vs $225.20 \pm 9.80 \mathrm{~g})$ and female rats $(96.40 \pm 4.15 \mathrm{~g}$ vs $97.60 \pm$ $2.17 \mathrm{~g}$ ) of the treated group and of the control group was observed. Similarly, the body weight gain in week 15 of the treated satellite male rats and the treated satellite female rats were not significantly different when compared to those of the control satellite rats $(270.86 \pm 10.40 \mathrm{~g}$ vs $242.00 \pm 10.07 \mathrm{~g}$ and $106.00 \pm 5.16$ g vs $115.00 \pm 6.67 \mathrm{~g}$, respectively).

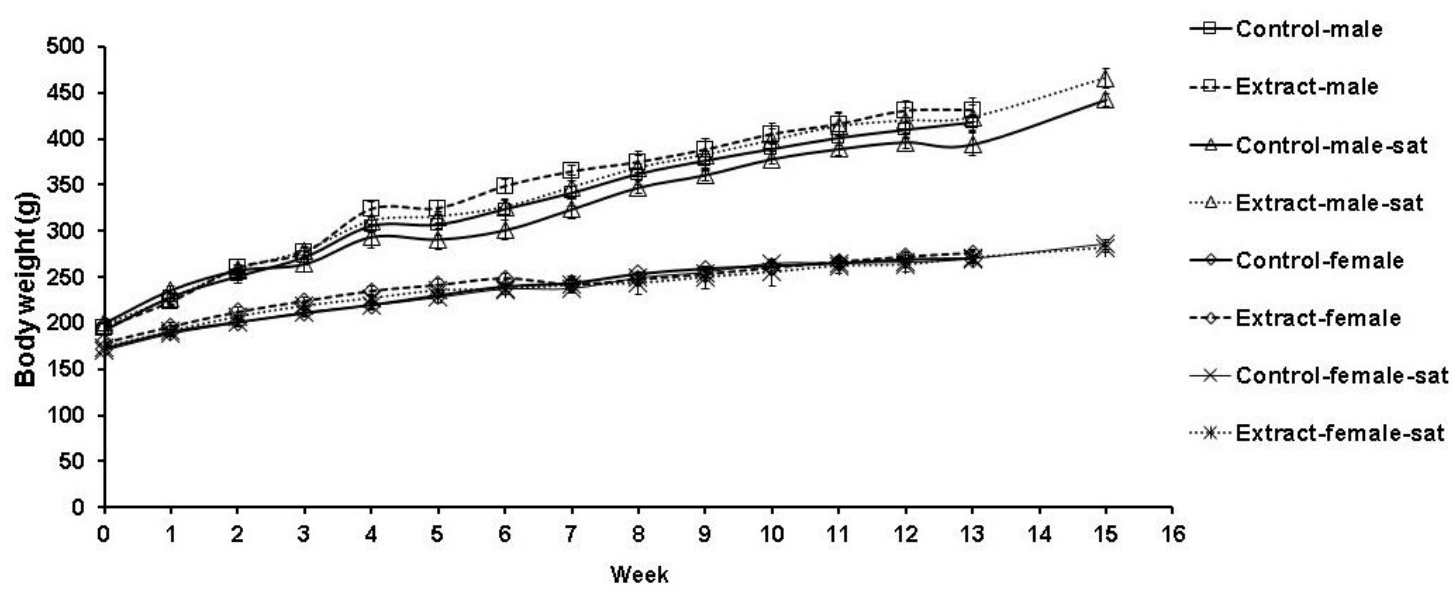

Figure 3. Body weight of the rats in repeated dose 90-day oral toxicity test.

The lung weight and the heart weight of the treated male rats were slightly but significantly lower and higher than those of the control group, respectively (Table 1). There was no significant difference between other organ weights of control and treated groups, and also organ weights of control satellite and treated satellite groups. The results obtained from histopathological examination of the internal organs showed no significant changes between the control, treated and satellite groups. No significant pathologic features between the groups were observed (Figure 4). 
Table 1. Organ weights (g/100g body weight) of rats in repeated dose 90 -day oral toxicity study of the water extract of the fresh leaf of $P$. palatiferum $1,000 \mathrm{mg} / \mathrm{kg}$.

\begin{tabular}{lllll}
\hline Organ & Control & Extract & Control-sat & Extract-sat \\
\hline Male rat & & & & \\
Brain & $0.52 \pm 0.01$ & $0.51 \pm 0.01$ & $0.48 \pm 0.01$ & $0.45 \pm 0.01$ \\
Lung & $0.65 \pm 0.08$ & $0.47 \pm 0.02^{*}$ & $0.51 \pm 0.04$ & $0.45 \pm 0.02$ \\
Heart & $0.36 \pm 0.01$ & $0.41 \pm 0.01^{*}$ & $0.37 \pm 0.01$ & $0.39 \pm 0.01$ \\
Liver & $3.09 \pm 0.10$ & $3.03 \pm 0.12$ & $3.00 \pm 0.08$ & $2.80 \pm 0.14$ \\
Spleen & $0.22 \pm 0.01$ & $0.23 \pm 0.01$ & $0.23 \pm 0.00$ & $0.21 \pm 0.01$ \\
Pancreas & $0.40 \pm 0.05$ & $0.39 \pm 0.03$ & $0.28 \pm 0.02$ & $0.26 \pm 0.02$ \\
Kidneys & $0.37 \pm 0.01$ & $0.38 \pm 0.01$ & $0.37 \pm 0.01$ & $0.32 \pm 0.00^{\#}$ \\
Adrenal & $0.01 \pm 0.00$ & $0.01 \pm 0.00$ & $0.01 \pm 0.00$ & $0.01 \pm 0.00$ \\
Testis & $0.46 \pm 0.02$ & $0.45 \pm 0.02$ & $0.44 \pm 0.01$ & $0.41 \pm 0.02$ \\
Female rat & & & & \\
Brain & $0.71 \pm 0.01$ & $0.75 \pm 0.01$ & $0.67 \pm 0.02$ & $0.70 \pm 0.02$ \\
Lung & $0.63 \pm 0.04$ & $0.63 \pm 0.05$ & $0.66 \pm 0.05$ & $0.59 \pm 0.04$ \\
Heart & $0.42 \pm 0.02$ & $0.40 \pm 0.01$ & $0.42 \pm 0.01$ & $0.38 \pm 0.02$ \\
Liver & $3.18 \pm 0.04$ & $2.97 \pm 0.25$ & $2.96 \pm 0.07$ & $3.10 \pm 0.04$ \\
Spleen & $0.31 \pm 0.02$ & $0.29 \pm 0.01$ & $0.25 \pm 0.01$ & $0.25 \pm 0.01$ \\
Pancreas & $0.38 \pm 0.03$ & $0.39 \pm 0.03$ & $0.33 \pm 0.03$ & $0.39 \pm 0.03$ \\
Kidneys & $0.41 \pm 0.01$ & $0.39 \pm 0.01$ & $0.36 \pm 0.01$ & $0.38 \pm 0.01$ \\
Adrenal & $0.01 \pm 0.00$ & $0.01 \pm 0.00$ & $0.01 \pm 0.00$ & $0.01 \pm 0.00$ \\
Ovary & $0.02 \pm 0.00$ & $0.02 \pm 0.00$ & $0.02 \pm 0.00$ & $0.02 \pm 0.00$ \\
Uterus & $0.33 \pm 0.04$ & $0.33 \pm 0.03$ & $0.25 \pm 0.01$ & $0.31 \pm 0.04$ \\
\hline
\end{tabular}

Note: Values are expressed as mean \pm S.E.M., $\mathrm{n}=10$. A satellite group was given distilled water (control-sat) or $P$. palatiferum extract at $1,000 \mathrm{mg} / \mathrm{kg}$ daily (extract-sat) over 90 days followed by no treatment for 14 days. *Significantly different when compared control and extract groups $(P<0.05)$. "Significantly different when compared control satellite and extract satellite groups $(P<0.05)$. 
Control

Liver
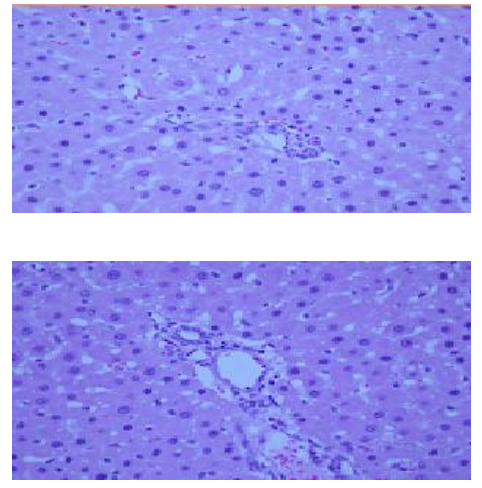

P. palatiferum

$1,000 \mathrm{mg} / \mathrm{kg}$
Kidney
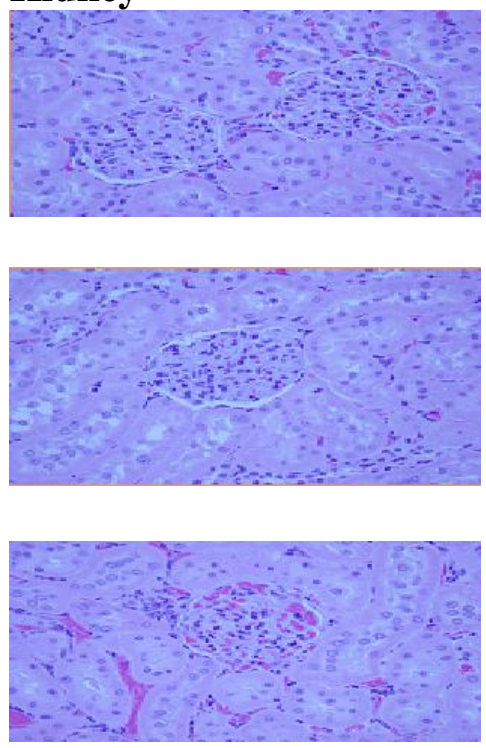

Figure 4. Histopathology of the liver and kidney of rats in repeated dose 90-day oral toxicity test at 40x magnification (haematoxylin-eosin stain).

The results from hematological examination showed no difference between control and treated groups in male rats, whereas the hemoglobin (HB) level of treated satellite female rats was slightly lower when compared with the control satellite rats but the difference was not clinically significant (Table 2). WBC count of treated male rats was slightly higher when compared to that of the control rats. The differential WBC counts have not observed the significant difference between control and treated groups in both male and female rats.

Table 2. Hematological values and differential white blood cell counts of rats in repeated dose 90-day oral toxicity study of the water extract of the fresh leaf of $P$. palatiferum $1,000 \mathrm{mg} / \mathrm{kg}$.

\begin{tabular}{|c|c|c|c|c|}
\hline Parameter & Control & Extract & Control-sat & Extract-sat \\
\hline \multicolumn{5}{|l|}{ Male rats } \\
\hline $\operatorname{HCT}(\%)$ & $53.00 \pm 0.71$ & $54.30 \pm 0.83$ & $53.89 \pm 1.20$ & $53.57 \pm 1.17$ \\
\hline $\mathrm{HB}(\mathrm{g} / \mathrm{dL})$ & $16.23 \pm 0.24$ & $16.75 \pm 0.21$ & $15.44 \pm 0.22$ & $15.36 \pm 0.27$ \\
\hline $\mathrm{RBC}\left(\mathrm{x} 10^{6}\right.$ cells $\left./ \mu \mathrm{L}\right)$ & $9.88 \pm 0.19$ & $10.08 \pm 0.17$ & $10.33 \pm 0.22$ & $10.41 \pm 0.25$ \\
\hline MCV (fL) & $53.60 \pm 0.48$ & $53.80 \pm 0.36$ & $52.00 \pm 0.37$ & $51.43 \pm 0.43$ \\
\hline MCH (pg) & $16.44 \pm 0.23$ & $16.60 \pm 0.15$ & $14.98 \pm 0.33$ & $14.74 \pm 0.16$ \\
\hline $\operatorname{MCHC}(\mathrm{g} / \mathrm{dL})$ & $30.64 \pm 0.30$ & $30.88 \pm 0.21$ & $28.82 \pm 0.55$ & $28.70 \pm 0.31$ \\
\hline PLT $\left(\times 10^{4}\right.$ cells $\left./ \mu \mathrm{L}\right)$ & $84.95 \pm 2.48$ & $84.95 \pm 1.39$ & $97.74 \pm 3.85$ & $94.90 \pm 4.69$ \\
\hline $\mathrm{WBC}\left(\mathrm{x} 10^{3}\right.$ cells $\left./ \mu \mathrm{L}\right)$ & $5.49 \pm 0.30$ & $6.81 \pm 0.52 *$ & $5.17 \pm 0.37$ & $4.88 \pm 0.64$ \\
\hline NEU (\%) & $15.70 \pm 0.73$ & $17.50 \pm 1.08$ & $15.33 \pm 1.42$ & $15.57 \pm 1.29$ \\
\hline $\operatorname{LYMP}(\%)$ & $82.60 \pm 0.92$ & $80.000 \pm 1.52$ & $78.78 \pm 1.37$ & $76.86 \pm 0.77$ \\
\hline MONO (\%) & $1.60 \pm 0.22$ & $2.10 \pm 0.80$ & $5.45 \pm 1.03$ & $7.57 \pm 0.95$ \\
\hline $\operatorname{EOS}(\%)$ & $0.10 \pm 0.10$ & $0.40 \pm 0.22$ & $0.45 \pm 0.18$ & $0.00 \pm 0.00$ \\
\hline BASO (\%) & $0.00 \pm 0.00$ & $0.00 \pm 0.00$ & $0.00 \pm 0.00$ & $0.00 \pm 0.00$ \\
\hline
\end{tabular}


Table 2. Continued.

\begin{tabular}{|c|c|c|c|c|}
\hline Parameter & Control & Extract & Control-sat & Extract-sat \\
\hline \multicolumn{5}{|l|}{ Female rats } \\
\hline HCT (\%) & $45.40 \pm 0.91$ & $45.50 \pm 0.92$ & $47.30 \pm 0.67$ & $45.43 \pm 1.49$ \\
\hline $\mathrm{HB}(\mathrm{g} / \mathrm{dL})$ & $14.46 \pm 0.22$ & $14.45 \pm 0.23$ & $15.65 \pm 0.28$ & $14.71 \pm 0.41^{\#}$ \\
\hline $\mathrm{RBC}\left(\mathrm{x} 10^{6}\right.$ cells $\left./ \mu \mathrm{L}\right)$ & $8.31 \pm 0.14$ & $8.31 \pm 0.19$ & $8.67 \pm 0.17$ & $8.45 \pm 0.27$ \\
\hline MCV (fL) & $54.50 \pm 0.27$ & $54.60 \pm 0.40$ & $54.60 \pm 0.54$ & $54.00 \pm 0.00$ \\
\hline $\mathrm{MCH}(\mathrm{pg})$ & $17.44 \pm 0.11$ & $17.41 \pm 0.17$ & $18.17 \pm 0.67$ & $17.40 \pm 0.10$ \\
\hline $\mathrm{MCHC}(\mathrm{g} / \mathrm{dL})$ & $31.94 \pm 0.230$ & $31.95 \pm 0.19$ & $32.15 \pm 0.16$ & $32.29 \pm 0.19$ \\
\hline PLT $\left(\times 10^{4}\right.$ cells $\left./ \mu \mathrm{L}\right)$ & $69.26 \pm 3.35$ & $69.09 \pm 4.24$ & $80.49 \pm 6.16$ & $74.99 \pm 4.67$ \\
\hline $\mathrm{WBC}\left(\times 10^{3}\right.$ cells $\left./ \mu \mathrm{L}\right)$ & $3.81 \pm 0.78$ & $3.61 \pm 0.51$ & $3.86 \pm 0.20$ & $2.60 \pm 0.31$ \\
\hline NEU $(\%)$ & $20.90 \pm 2.70$ & $19.90 \pm 3.29$ & $21.90 \pm 1.36$ & $19.12 \pm 2.12$ \\
\hline LYMP (\%) & $74.40 \pm 2.27$ & $75.90 \pm 3.11$ & $74.70 \pm 1.48$ & $76.86 \pm 2.15$ \\
\hline MONO (\%) & $4.56 \pm 0.86$ & $3.90 \pm 0.60$ & $3.40 \pm 0.82$ & $4.00 \pm 0.87$ \\
\hline EOS $(\%)$ & $0.20 \pm 0.13$ & $0.30 \pm 0.15$ & $0.00 \pm 0.00$ & $0.00 \pm 0.00$ \\
\hline BASO $(\%)$ & $0.00 \pm 0.00$ & $0.00 \pm 0.00$ & $0.00 \pm 0.00$ & $0.00 \pm 0.00$ \\
\hline
\end{tabular}

Note: Values are expressed as mean \pm S.E.M., $n=10$. A satellite group was given distilled water (control-sat) or P. palatiferum extract at $1,000 \mathrm{mg} / \mathrm{kg}$ daily (extract-sat) over 90 days followed by no treatment for 14 days. HCT hematocrit, HB hemoglobin, RBC red blood cell count, MCV mean corpuscular volume, $\mathrm{MCH}$ mean corpuscular hemoglobin, MCHC mean corpuscular hemoglobin concentration, PLT platelet count, WBC white blood cell count, NEU neutrophil, LYMP lymphocyte, MONO monocyte, EOS eosinophil, BASO basophil.*Significantly different when compared control and extract groups $(P<0.05)$. "Significantly different when compared control satellite and extract satellite groups $(P<0.05)$. Red blood cell count (RBC), mean corpuscular volume (MCV), mean corpuscular hemoglobin $(\mathrm{MCH})$, mean corpuscular hemoglobin concentration (MCHC), white blood cell count (WBC).

The blood biochemistry values of the male and female rats are shown in Table 3. The increase of glucose levels was noted in the male rats received the extract when compared with that of the control rats. Some blood chemistry values including creatinine (CRE), aspartate aminotransferase (AST), alkaline phosphatase (ALP), total protein (TP) and albumin (ALB) of the extract groups and the extract satellite groups were slightly different when compared with those of control and control satellite groups, respectively. Merely alanine aminotransferase (ALT) value of the treated female rats was slightly lower than that of the control rats, other values were not significantly different from the control groups. 
Table 3. Blood chemistry values of rats in repeated dose 90-day oral toxicity study of the water extract of the fresh leaf of $P$. palatiferum 1,000 $\mathrm{mg} / \mathrm{kg}$.

\begin{tabular}{lcccc}
\hline Parameter & Control & Extract & Control-sat & Extract-sat \\
\hline Male rats & & & & \\
GLU (mg/dL) & $111.60 \pm 6.41$ & $194.10 \pm 14.20^{*}$ & $154.44 \pm 7.44$ & $128.57 \pm 8.02^{\#}$ \\
BUN (mg/dL) & $21.02 \pm 0.46$ & $19.68 \pm 0.59$ & $40.54 \pm 18.33$ & $19.13 \pm 0.76$ \\
CRE (mg/dL) & $0.59 \pm 0.02$ & $0.65 \pm 0.02^{*}$ & $0.61 \pm 0.01$ & $0.64 \pm 0.01^{\#}$ \\
AST (U/L) & $86.50 \pm 4.52$ & $113.70 \pm 9.34^{*}$ & $101.44 \pm 6.81$ & $114.29 \pm 10.49$ \\
ALT (U/L) & $36.40 \pm 2.39$ & $39.30 \pm 2.91$ & $40.22 \pm 1.87$ & $36.71 \pm 2.04$ \\
ALP (U/L) & $60.50 \pm 3.76$ & $57.40 \pm 1.73$ & $58.56 \pm 2.50$ & $51.14 \pm 2.15^{\#}$ \\
T-BIL (mg/dL) & $0.08 \pm 0.00$ & $0.07 \pm 0.00$ & $0.08 \pm 0.01$ & $0.09 \pm 0.01$ \\
D-BIL (mg/dL) & $0.06 \pm 0.00$ & $0.05 \pm 0.00$ & $0.06 \pm 0.01$ & $0.05 \pm 0.00$ \\
TP (g/dL) ALB & $5.79 \pm 0.13$ & $5.77 \pm 0.14$ & $5.67 \pm 0.06$ & $5.34 \pm 0.06^{\#}$ \\
(g/dL) & $3.03 \pm 0.04$ & $2.89 \pm 0.02 *$ & $3.19 \pm 0.03$ & $3.04 \pm 0.02^{\#}$ \\
& & & & \\
Female rats & & & & \\
GLU (mg/dL) & $110.80 \pm 5.95$ & $130.20 \pm 8.36$ & $155.00 \pm 6.50$ & $173.00 \pm 25.50$ \\
BUN (mg/dL) & $25.49 \pm 1.03$ & $26.55 \pm 0.73$ & $26.40 \pm 1.41$ & $25.34 \pm 1.05$ \\
CRE (mg/dL) & $0.71 \pm 0.03$ & $0.70 \pm 0.02$ & $0.69 \pm 0.02$ & $0.76 \pm 0.05$ \\
AST (U/L) & $117.10 \pm 21.96$ & $91.00 \pm 5.90$ & $93.20 \pm 5.88$ & $148.71 \pm 48.92$ \\
ALT (U/L) & $42.20 \pm 5.48$ & $31.10 \pm 0.84 *$ & $40.20 \pm 3.15$ & $37.86 \pm 5.00$ \\
ALP (U/L) & $71.20 \pm 30.50$ & $49.80 \pm 3.88$ & $52.40 \pm 4.23$ & $39.14 \pm 4.54$ \\
T-BIL (mg/dL) & $0.09 \pm 0.00$ & $0.08 \pm 0.00$ & $0.10 \pm 0.01$ & $0.09 \pm 0.01$ \\
D-BIL (mg/dL) & $0.06 \pm 0.00$ & $0.06 \pm 0.00$ & $0.07 \pm 0.01$ & $0.06 \pm 0.00$ \\
TP (g/dL) ALB & $5.81 \pm 0.09$ & $6.04 \pm 0.15$ & $5.98 \pm 0.11$ & $5.90 \pm 0.15$ \\
(g/dL) & $3.06 \pm 0.04$ & $3.17 \pm 0.07$ & $3.32 \pm 0.05$ & $3.17 \pm 0.04$ \\
\hline
\end{tabular}

Note: Values are expressed as mean \pm S.E.M., $n=10$. A satellite group was given distilled water (control-sat) or P. palatiferum extract at $1,000 \mathrm{mg} / \mathrm{kg}$ daily (extract-sat) over 90 days followed by no treatment for 14 days. GLU glucose, BUN blood urea nitrogen, CRE creatinine, AST aspartate aminotransferase, ALT alanine aminotransferase, ALP alkaline phosphatase, T-BIL total bilirubin, D-BIL direct bilirubin, TP total protein, ALB albumin. *Significantly different when compared control and extract groups $(P<0.05)$. "Significantly different when compared control satellite and extract satellite groups $(P<0.05)$.

\section{DISCUSSION}

As the fresh leaf of $P$. palatiferum has been used to treat chronic diseases, the present study performed to provide scientific data for the safety profile of the water extract in acute and chronic uses. The result from HPLC analysis demonstrated a few components of gallic acid and tannic acid in the water extract, besides the unknown major peaks, have shown. The previous HPLC profile of 95\% ethanol extract of the fresh leaf of $P$. palatiferum has shown the component of gallic acid, tannin acid, catechin, rutin, isoquercetin, quercetin and kaempferol (Sittisart et al., 2016). The present study provided a different result from the previous report in the chemical compositions because of the difference in the 
method of extraction. As a result of the limitation of the chemical markers and the system, further investigation to identify the unknown constituents should be studied. According to the traditional remedy uses of 7 to 9 fresh leaves for the treatment chronic diseases (Dieu et al., 2005) or nearly $10 \mathrm{~g}$ of the raw materials which is calculated to approximate $0.57 \mathrm{~g}$ of the extract. The present study used $2,000 \mathrm{mg} / \mathrm{kg}$ and $1,000 \mathrm{mg} / \mathrm{kg}$ of the extract in acute and repeated dose 90 -day oral toxicity tests, respectively, which are more 1,000 times higher than usual doses as traditional medicine. The results from the present study showed that the single oral administration of $2,000 \mathrm{mg} / \mathrm{kg}$ of the extract to female rats did not cause mortality or any signs of toxicity throughout the observation period. Neither death nor toxic signs were observed during repeated administration for 90 days of the extract at a daily dose of $1,000 \mathrm{mg} / \mathrm{kg}$ to both sexes of rats.

Either reduction of body weight or reduction of internal organ weight is used to evaluate the toxicity of substances. Additionally, histopathological examination of the internal organs was performed to find out any cellular damage. Some test substances may not show any observable disorders but harm to tissues at the cellular level (Teo et al., 2003). For this reason, the organs were weighed immediately after the sacrifice of animals and then were histopathologically examined. The lower value of the lung weight and the higher value of the heart weight of treated male rats compared to those of control male rats were observed, however, these differences returned into normal values since there was no difference in organ weight between control satellite and treated satellite groups. Additionally, results from the histopathological examination revealed no changes in the internal organs or tissues of the treated rats. Hematological values, differential WBC counts and blood chemistry values of both treated male and female rats were similar to those of the control rats except the blood glucose level of the treated male rats. However, the high blood glucose level was temporary since the level was decreased in the treated satellite male rats. Although the levels of CRE, AST, ALP, TP and ALB of the treated rats and the treated satellite rats were slightly different when compared with those of the control rats and the control satellite rats, respectively, but these values were within the normal ranges of Sprague Dawley rats of the National Laboratory Animal Center, Nakorn Pathom, Thailand (Butadej et al., 2011). Because there was no sign of toxicity noted regarding organ weights, gross and the histopathological examinations of the internal organs, hematological examination, and clinical chemistry, the noobserved-adverse-effect level (NOAEL) of the water extract of the fresh leaf of $P$. palatiferum is considered to be greater than $1,000 \mathrm{mg} / \mathrm{kg} /$ day. However, considering the safety of use in humans, the effect of the extract should be monitored on the function of the lung, the heart, and the liver. 


\section{CONCLUSION}

In conclusion, the single oral administration of $2,000 \mathrm{mg} / \mathrm{kg}$ of the water extract of the fresh leaf of $P$. palatiferum produces neither any signs of acute toxicity nor mortality in female rats. The daily dose of $1,000 \mathrm{mg} / \mathrm{kg}$ of the extract repeated for 90 days reveals well tolerance and safety profile in both sexes of rats. However, the further toxicity study using non-rodent species, the genotoxicity, and the unknown components should be investigated.

\section{ACKNOWLEDGEMENTS}

The authors thank the Thailand Research Fund (TRF) for providing financial support.

\section{REFERENCES}

Buncharoen, W., Saenphet, S., and Saenphet, K. 2010. Acetylcholinesterase inhibitory effect of Pseuderanthemum palatiferum in albino rats. Trends Research in Science and Technology. 2(1): 13-8.

Butadej, D., Duangchanchot, M., Inpunkaew, R., and Kengkoom, K. 2011. Chemical parameters in healthy Sprague-Dawley and Wistar rats from National LaboratoryAnimal Center, Mahidol University. The proceedings of $49^{\text {th }}$ Kasetsart University Annual Conference, subject: science. Kasetsart University. Febuary 1-4, 2011. p.322-329. http://www.lib.ku.ac.th/ KUCONF/2555/KC4905042.pdf

Dechayont, B., Sukkan, B., Intouch Sakpakdeejaroen, I., and Itharat, A. 2010. Study on cytotoxic and antioxidant activities of Pseuderathemum platiferum. Thai Journal of Pharmacology. 32(1): 50-53.

Dieu, H.K., Loc, C. B., Yamasaki, S., and Hirata, Y. 2005. The ethnobotanical and botanical study on Pseuderanthemum palatiferum as a new medicinal plant in the mekong delta of Vietnam. Japan Agricultural Research Quarterly. 39(3): 191-196. https://doi.org/10.6090/jarq.39.191

Dieu, H.K., Loc, C.B., Yamasaki, S., and Hirata, Y. 2006. The effects of Pseuderanthemum palatiferum, a new medicinal plant, on growth performances and diarrhea of piglets. Japan Agricultural Research Quarterly. 40: 85-91. https://doi.org/10.6090/jarq.40.85

Inchab, K., Khonsung, P., Chiranthanut, N., Kunanusorn P., Potikanond, S., Chansakaow, S., and Sireeratawong, S. 2018. Anti-gastric ulcer activity of the water extract from payawanorn (Pseuderanthemum Palatiferum). Journal of Health Science and Medical Research. 36(2): 89-95. https://doi.org/10.31584/jhsmr.2018.36.2.1 
Inchab, K., Khonsung, P., Chiranthanut, N., Kunanusorn P., Panthong, A., and Sireeratawong, S. 2019. Evaluation of anti-inflammatory, analgesic, and antipyretic activities of Pseuderanthemum palatiferum. Chiang Mai University Journal of Natural Sciences. 18(3): 393-407. https://doi.org/ 10.12982/CMUJNS.2019.0027

Khonsung, P., Panthong, A., Chiranthanut, N., and Intahphuak, S. 2011. Hypotensive effect of the water extract of the leaves of Pseuderanthemum palatiferum. Journal of Natural Medicines. 65(3): 551-558. https://doi.org/ 10.1007/s11418-011-0540-Z

Khumpook, T., Chomdej, S., Saenphet, S., Amornlerdpison, D., and Saenphet, K. 2013. Anti-inflammatory activity of ethanol extract from the leaves of Pseuderanthemum palatiferum (Nees) Radlk. Chiang Mai Journal of Science. 40(3): 321-331.

Kongprasom, U., Sukketsiri, W., Chonpathompikunlert, P., Sroyraya, M., Sretrirutchai, S., and Tanasawet, S. 2019. Pseuderanthemum palatiferum (Nees) Radlk extract induces apoptosis via reactive oxygen speciesmediated mitochondria-dependent pathway in A549 human lung cancer cells. Tropical Journal of Pharmaceutical Research. 18(2): 287-294. https:// doi.org/10.4314/tjpr.v18i2.10

Komonrit, P., and Banjerdpongchai, R. 2018. Effect of Pseuderanthemum palatiferum (Nees) Radlk fresh leaf ethanolic extract on human breast cancer MDA-MB-231 regulated cell death. Tumour Biology. 40(9): 1-14. https://doi.org/10.1177/1010428318800182

Nguyen, Q.V., and Eun J.B. 2013. Antimicrobial activity of some Vietnamese medicinal plants extracts. Journal of Medicinal Plants Research. 7(35): 2597-2605. https://doi.org/10.5897/JMPR2013.4452

OECD Guidelines for the Testing of Chemicals. 2002. Test No. 420: Acute oral toxicity-fixed dose procedure. ECD Guidelines for the Testing of Chemicals, Section 4, OECD Publishing, Paris. https://doi.org/10.1787/ 9789264070943-en

OECD Guidelines for the Testing of Chemicals. 2018. Test No. 408: Repeated dose 90-day oral toxicity study in rodents. OECD Guidelines for the Testing of Chemicals, Section 4, OECD Publishing, Paris. https://doi.org/ 10.1787/9789264070707-en

Padee, P., and Nualkaew, S. 2009. Current information of medicinal plants: Pseuderanthemum Palatiferum (Nees) Radlk. Journal of Health Science. 18(1): 131-138.

Padee, P., Nualkeaw, S., Talubmook, C., and Sakuljaitrong, S. 2009. Acute toxicity and sub-acute toxicity of Pseuderanthemum palatiferum (Nees) Radlk. leaf extract. Isan Journal of Pharmaceutical Sciences. 5: 74-81. 
Padee, P., Nualkaew, S., Talubmook, C., and Sakuljaitrong, S. 2010. Hypoglycemic effect of a leaf extract of Pseuderanthemum palatiferum (Nees) Radlk. in normal and streptozotocin-induced diabetic rats. Journal of Ethnopharmacology. 132: 491-496. https://doi.org/10.1016/j.jep.2010. 07.056

Panomket, P., and Wanram, S. 2011. Hoan Ngoc activity in streptozotocininduced diabetic mice. Isan Journal of Pharmaceutical Sciences. 7(2) : 2228.

Sittisart, P., Chitsomboon, B., and Kaminski, N.E. 2016. Pseuderanthemum palatiferum leaf extract inhibits the proinflammatory cytokines, TNF-a and IL-6 expression in LPS-activated macrophages. Food and Chemical Toxicology. 97: 11-22. https://doi.org/10.1016/j.fct.2016.08.021

Teo, S.K., Stirling, D.I., Thomas, S.D., Evans, M.G., and Khetani, V.D. 2003. A 90-day oral gavage toxicity study of d-methylphenidate and d,l-methylphenidate in beagle dogs. International Journal of Toxicology. 22: 215-226. https://doi.org/10.1080/10915810305100 